\title{
PENGARUH HARGA KOMODITAS PANGAN TERHADAP INFLASI DI KOTA PANGKALPINANG 2015-2017.
}

\author{
Irnawati $^{1}$ \\ Universitas Bangka Belitung \\ irnawat680@gmail.com
}

\begin{abstract}
Abstrak
Penelitian ini dilakukan dengan pendekatan kuantitatif melalui data sekunder,wawancara dan observasi . Alat analisis yang digunakan adalah Model Regresi Berganda, dan Uji Asumsi Klasik (Uji Stasioner, Normalitas, Multiklonieritas, Heteroskedastisitas, dan Autokorelasi). Hai Penelitian menunjukan koefisien determinasi atau R-square sebesar 0,553712 ini berarti variasi inflasi dapat dijelaskan oleh variasi harga komoditas pangan sebesar 55,3 persen atau menunjukkan bahwa variasi harga komoditas pangan ini mampu mempengaruhi inflasi sebesar 55,3 persen dan sisanya dijelaskan oleh variabel lainnya. Komoditas pangan ikan tenggiri memiliki pengaruh positif dan signifikan terhadap inflasi di Kota Pangkalpinang, sedangkan yang berpengaruh negatif terhaap tingkat inflasi adalah sayuran dan telur.
\end{abstract}

\section{PENDAHULUAN}

Inflasi adalah fenomena ekonomi yang sangat dikhawatirkan oleh seluruh dunia, khususnya negara indonesia yang merupakan negara berkembang. Masalah inflasi ini sangatlah kompleks, dan berpengaruh terhadap harga komoditas pangan. Sekarang ini, komoditas pangan telah menjadi penyumbang inflasi di Kota Pangkalpinang. Setelah dirilis oleh Badan Pusat Statistik, ternyata dari tahun ke tahun harga komoditas pangan semakin meningkat dan akan berdampak pada tingkat inflasi di Indonesia. komoditas pangan sendiri memiliki arti yaitu segala hal yang dapat dikonsumsi berasal dari tanah dan air serta menjadi sumber hayati didalamnya dan dapat digunakan oleh manusia sebagai bahan makanan. Bahan makanan tersebut, harus mengandung zat besi, karbohidrat, protein, lemak, vitamin dan mineral. Komoditas pangan memiliki manfaat bagi kesehatan dan pertumbuhan tubuh.

Komoditas pangan ternyata memiliki kontribusi yang penting dalam berbagai aspek diantaranya yaitu ekonomi, sosial, maupun politik (Prabowo, 2014). Pengaruh komoditas pangan sendiri yaitu adanya kestabilan diseminasi permintaan dan penawaran. Harga komoditas pangan memiliki sifat berfluktuasi disebabkan oleh beberapa faktor yaitu, adanya kelangkaan pasokan bahan pangan, tingginya permintaan masyarakat, cuaca buruk serta adanya gangguan hama pada tanaman pangan. Di dalam negeri, harga komoditas pangan yang menjadi sorotan publik untuk penyumbang inflasi dan deflasi adalah beras, jagung, kedelai, tepung terigu, gula pasir, minyak goreng, bawang merah, cabe, telur, daging, ikan-ikan segar, dan susu (Sumaryanto, 2009).

Leading indicators inflasi telah menjadi pergerakan harga komoditas. Alasannya, karena harga komoditas mampu memberikan respon yang cepat (shock) dalam perekonomian secara umum, seperti kenaikan permintaan agregat ( aggregate demand 
shock) dan harga komoditas juga berupaya merespon terhadap non economic shock, seperti : terjadinya banjir, tanah longsor, gempa bumi dan bencana alam. Hal ini yang dapat menjadi penghambat penyaluran komoditas tersebut.

Inflasi diartikan sebagai kenaikan harga barang dan jasa secara umum yang terjadi terus menurus. Jika inflasi ditekan maka dapat mengakibatkan tingginya tingkat pengangguran, kemiskinan, dan indeks pembangunan manusia. Di Indonesia, angka inflasi dikeluarkan oleh Badan Pusat Statistik melalui perhitungan Indeks Harga Konsumen (IHK). IHK adalah suatu indeks yang menghitung rata-rata perubahan harga dari suatu kumpulan barang dan jasa yang dikonsumsi oleh rumah tangga dalam kurun waktu tertentu. Inflasi terjadi karena adanya kenaikan harga yang ditunjukkan oleh naiknya tujuh pengeluaran, yaitu bahan makanan, perumahan, sandang, kesehatan, pendidikan, rekreasi dan olahraga serta transportasi, komunikasi dan jasa keuangan. Dari tujuh kelompok pengeluaran, kelompok bahan makanan yang sering mengalami kenaikan harga baik disebabkan oleh tekanan permintaan atau karena berkurangnya penawaran.

Kota Pangkalpinang merupakan pusat perdagangan dan jasa komersil untuk daerah di Provinsi Kepulauan Bangka Belitung. Struktur ekonomi Kota Pangalpinang mempunyai peranan yang tinggi terhadap kegiatan perdagangan dan telah berkembang pesat. Di Kota Pangkalpinang Bahan makanan memiliki Andil Inflasi/ Deflasi tertinggi pada bulan juli 2018 sebesar 0,73 persen (Lampiran 1). Hal ini dikarenakan adanya perayaan keagaman pada bulan-bulan tertentu sehingga menyebabkan pola makanan masyarakat Kota Pangkalpinang meningkat drastis. Sebagai daerah kepulauan, Provinsi Kepulauan Bangka Belitung sangat sensetif terhadap kerawanan komoditi pangan, seperti ketersediaan beras.Beras di Provinsi Kepulauan Bangka Belitung masih menggantungkan ke daerah lain. Hal ini disebabkan adanya cuaca yang kurang bersahabat, seperti tingginya gelombang air laut, dan musim kemarau yang berkepanjangan. Saat ini, kebutuhan beras di Babel sebesar 113.304 ton sedangkan produksi beras yang tersedia hanya 9.453 ton (BKP Babel, 2012). Dalam kontes ketahanan pangan, ketergantungan ini sangat beresiko terhadap masyarakat dan mengakibatkan Kota Pangkalpinang tidak bisa mencukupi kebutuhan bahan pangan sendiri, sehingga masih begantung pada daerah lain. Dengan tingginya tingkat permintaan masyarakat dan ketersediaan yang menurun maka akan menciptakan kejutan harga yang melambung tinggi yang tentu akan berpengaruh terhadap besarnya inflasi

Pada penelitian di Badan Pusat Statistik, Sepuluh komoditas yang akan diketahui pengaruhnya terhadap inflasi, diantara yaitu: ikan kerisi, bayam, cabai rawit, ikan tenggiri, beras, cumi-cumi, telur ayam ras, jeruk dan juga apel. Sepuluh komoditas tersebut adalah komoditas bahan makanan yang diperoleh berdasarkan sub-sub makanan, seperti buahbuahan, makanan pokok (beras), sayuran, telur, rempah-rempah dan ikan segar. Bahan makanan yang diteliti untuk diketahui pengaruhnya diperoleh dari salah satu sub makanan dan telah menjadi andil inflasi/deflasi terbesar tahun 2015 - 2017dan (Lampiran 1), kecuali telur ayam ras yang dilihat dari fluktuasi harga pada setiap bulan (Tabel 8).

Berdasarkan data yang diperoleh dari Badan Pusat Staistik (BPS) dapat terlihat bahwa presentase inflasi Kota Pangkalpinang tahun 2018 sebesar 0,34\% dengan Indeks Harga Konsumen (IHK) sebesar 140,92 dan menduduki urutan ke-9 dari 23 kota IHK di Pulau Sumatra, sedangkan pada tahun 2017, presentase inflasi tahunan Kota Pangkalpinang sebesar 2,66 persen dengan Indeks Harga Konsumen (IHK) sebesar 136,95 dan menduduki urutan ke-21 dari 23 Kota IHK dipulau sumatra.

Berdasarkan gambar 1.1 di bawah ini, bahwa harga komoditas pangan di Kota Pangkalpinang memiliki pengaruh besar terhadap inflasi. Hal ini bertujuan untuk mengetahui seberapa besar pengaruh harga komoditas ikan kerisi, bayam, cabai rawit, ikan tenggiri, sawi hijau, beras, telur ayam ras, cumi-cumi, jeruk dan Apel terhadap inflasi di Kota Pangkalpinang pada tahun 2015-2017. 


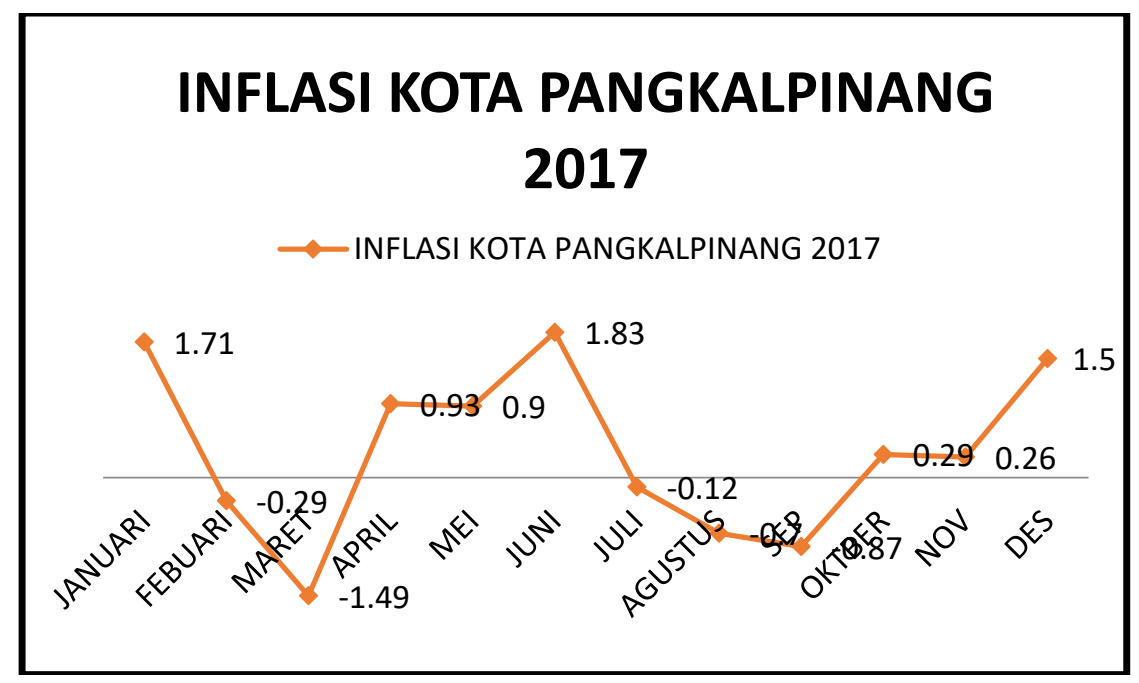

Gambar 1.1 Inflasi Kota Pangkalpinang

Sumber: Badan Pusat Statistik Provinsi Kepulauan Bangka Belitung (2017)

\section{TINJAUAN PUSTAKA}

\subsection{Harga Komoditas Pangan}

Menurut Kotler dan Amstrong (2012: 345) harga diartikan secara sempit adalah jumlah uang yang ditagihkan untuk suatu produk atau jasa. Secara umum harga adalah nilai suatu barang dan jasa yang diukur dengan jumlah uang yang dikeluarkan oleh pembeli untuk mendapatkan sejumlah kombinasi dan barang dan jasa. Fungsi harga yaitu untuk menunjang aktivitas transaksi dimana saja, dengan terbentuknya harga aktivitas jual beli dapat berjalan dengan baik tanpa dibatasi oleh hal apapun. Selain itu harga dapat menjadi sumber pemasukan atau keuntungan bagi produsen.

Pangan merupakan komoditas yang strategis, karena fungsinya untuk memenuhi kebutuhan pokok manusia yang sekaligus bagian dari pemenuhan hak asasi dari setiap rakyat Indonesia (Riyadi, 2003). Hal ini tertuang di dalam Undang-Undang No 7 Tahun 1996 Tentang Pangan yang menyatakan tujuan pangan, yaitu mencapai kecukupan pangan akan menentukan kualitas sumber daya manusia dan sekaligus ketahanan bangsa. Untuk mencapai tujuan tersebut, kebijakan pangan dilakukan guna menjamin ketersediaan pangan dalam jumlah yang cukup, merata, aman, bermutu, bergizi, beragam, dan dapat dijangkau oleh daya beli masyarakat.

Pangan sendiri diartikan sebagai salah satu yang bersumber dari sumber hayati dan air, baik itu diolah maupun tidak diolah. Komoditas pangan diperuntukkan bagi konsumsi manusia sebagai bahan makanan atau minuman, termasuk bahan tambahan pangan, pengolahan, atau pembuatan makanan dan minuman.

Batasan untuk tanaman pangan adalah kelompok tanaman sumber karbohidrat dan protein. Namun, secara sempit, tanaman pangan biasanya dibatasi pada kelompok tanaman yang berumur semusim. Batasan ini dimasa mendatang harus diperbaiki karena akan menyebabkan sumber karbohidrat menjadi terbatas. Tanaman pangan sebaiknya memasukkan jenis tanaman lain yang dapat menjadi sumber karbohidrat tanpa dibatasi pada kelompok tanaman semusim. Dengan 
perbaikan batasan ini, tanaman umbian selain ubi kayu, ubi jalar, dan talas dapat masuk kedalam kelompok tanaman pangan. (Purwono dan Purnamawati, 2007).

\subsection{Inflasi}

Inflasi adalah kenaikan harga secara umum yang terjadi secara terus menurus (kontinu), inflasi disebabkan oleh dua hal diantaranya yaitu adanya permintaan masyarakat yang berlebihan dan adanya kenaikan biaya produksi (Boediono, 1992 : 162). Menurut Atmadja (1999 : 66) inflasi di Indonesia bukan hanya fenomena jangka pendek namun juga pada fenomena jangka panjang. Jadi dengan fenomena tersebut, inflasi merupakan sebuah fenomena moneter yang memiliki pengaruh yang luas kepada kondisi negara dalam makro ekonomi. Dengan hal tersebut, inflasi dapat terkendali dengan tujuan agar tetap rendah dan stabil.

Teori kuantitas adalah teori yang tertua yang membahas tentang inflasi, Teori ini menekankan pada peranan jumlah uang beredar, baik uang kartal maupun giral dan harapan (ekspektasi) masyarakat mengenai kenaikan harga terhadap timbulnya inflasi. Teori strukturalis merupakan salah satu teori yang terdapat pada inflasi yang didasarkan pada pengalaman di negara-negara di Amerika Latin.

Berdasarkan penyebab kenaikan harga - harga yang berlaku, inflasi dapat dikelompokan menjadi 3 yaitu:

1. Inflasi berdasarkan sifatnya

Inflasi berdasarkan sifatnya terdiri dari 4 macam yaitu:

1. Inflasi rendah yaitu inflasi yang mempunyai nilai kurang dari $100 \%$ pertahunnya.

2. Inflasi menengah yaitu inflasi yang nilainya antara $10-30 \%$ pertahun.

3. Inflasi berat yaitu inflasi yang besarnya antara $30-100 \%$ pertahun.

4. Inflasi tinggi (Hiper inflasi) yaitu inflasi yang ditandai dengan naiknya harga barang secara drastis hingga mencapai 4 digit (diatas 100\%).

2. Inflasi berdasarkan sebabnya (Nopirin : 2010)

Inflasi berdasarkan sebabnya dibagi atas 3 bagian yaitu :

1. Tarik permintaan (Demand pull inflation)

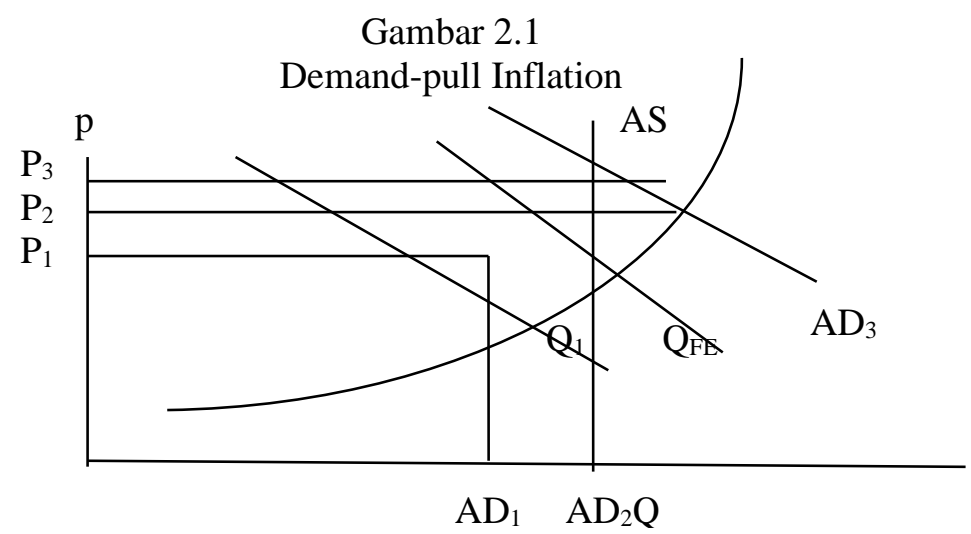

Inflasi ini bermula darı adanya kenaikan permintaan total (agregate demand), sedangkan produksi telah berada pada keadaan kesempatan kerja penuh atau hampir mendekati kesempatan kerja penuh. Dengan bermulanya harga $\mathrm{P}_{1}$ dan output sebesar $\mathrm{Q}_{1}$, terjadilah kenaikan permintaan total dari $\mathrm{AD}_{1}$ ke $\mathrm{AD}_{2}$ menyebabkan ada sebagian 
permintaan yang tidak dapat dipenuhi oleh penawaran yang ada. Akibatnya, harga naik menjadi $\mathrm{P}_{2}$ dan output naik menjadi $\mathrm{Q}_{\mathrm{EF}}$. Kenaikan $\mathrm{AD}_{2}$ menjadi $\mathrm{AD}_{3}$ menyebabkan harga naik menjadi $\mathrm{P} 3$ sedangkan output tetap pada $\mathrm{Q}_{\mathrm{FE}}$. Kenaikan harga ini disebabkan oleh inflationary gaya

2. Desakan biaya (Cost push inflation)

Gambar 2.2

Cost Push Inflation

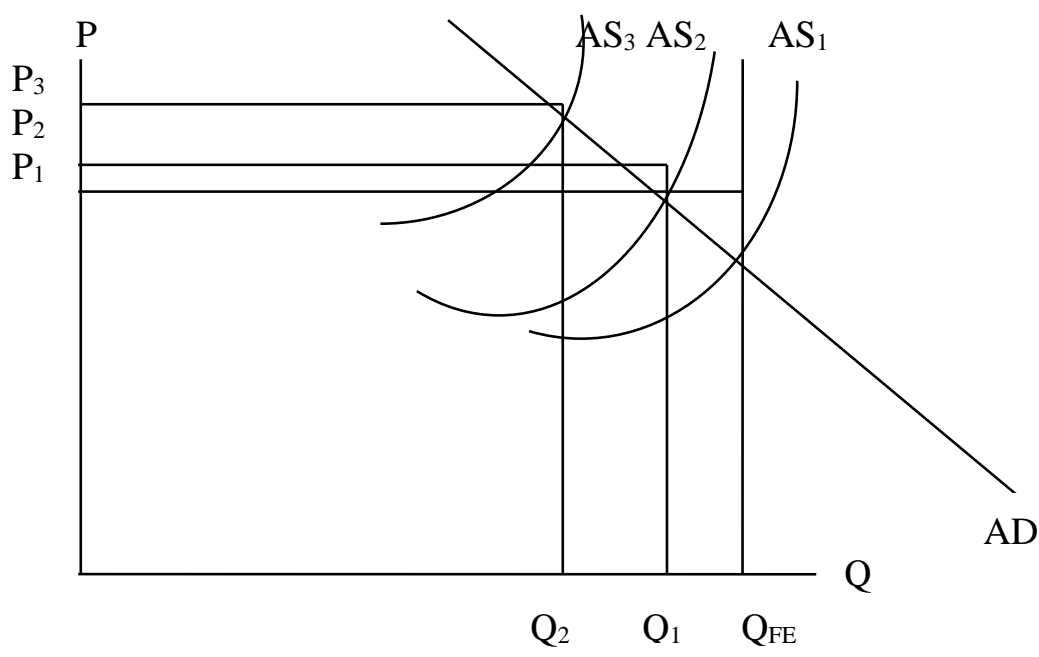

Cost push inflation biasanya ditandai dengan adanya kenaikan harga serta turunnya produksi. Bermula pada harga $\mathrm{P}_{1}$ dan $\mathrm{Q}_{\mathrm{FE}}$. Kenaikan biaya produksi (disebabkan karena berhasilnya tuntutan kenaikan upah oleh serikat buruh ataupun kenaikan harga bahan baku untuk industri) akan menggeser kurva penawaran total dari $\mathrm{AS}_{1}$ menjadi $\mathrm{AS}_{2}$. Konsekuensinya harga naik menjadi $\mathrm{P}_{2}$ dan produksi turun menjadi $\mathrm{Q}_{1}$. Kenaikan harga selanjutnya akan menggeser kurva AS menjadi $\mathrm{AS}_{3}$, Harga naik dan produksi turun menjadi $\mathrm{Q}_{2}$. Proses ini akan berhenti apabila AS tidak lagi menggeser keatas.

3. Inflasi campuran (Bottle neck inflation)

Inflasi berdasarkan asalnya

Inflasi berdasarkan asalnya terbagi menjadi 2 yaitu:

1. Domestic inflation.

2. Imported inflation.

Adapun dampak terjadinya inflasi adalah sebagai berikut:

1. Dampak atau akibat dari inflasi terhadap perekonomian suatu negara yaitu :

- Berkurangnya investor

- Mendorong tingkat suku bangsa

- Mendorong tingkat spekulatif

- Kegagalan pembangunan

- Ketidakpastian ekonomi masa yang akan datang

- Daya saing produk nasional berkurang

- Defisit neraca pembayaran 
- Kesejahteraan masyarakat menurun

2. Dampak atau akibat dari inflasi terhadap masyarakat adalah sebagai berikut :

- Masyarakat berpenghasilan tetap

- Kreditur atau debitur

- Memperbesar kesenjangan distribusi pendapatan

- Menguntungkan para spekulan

- Mempengaruhi para pelaku ekonomi

Adanya dampak inflasi yang terjadi, cara dalam mengatasi masalah tersebut adalah dengan dilakukan beberapa kbijakan-kebijakan diantaranya :

1. Kebijakan Moneter adalah kebijakan yang dilakukan oleh pemerintah dibidang keuangan dalam pengendalian uang dimasyarakat guna untuk menjaga kestabilan moneter agar inflasi dapat terkendalikan dalam meningkatkan kesejahteraan masyarakat.

2. Kebijakan Fiskal adalah kebijakan yang berhubungan dengan finansial pemerintah seperti menaikkan tarif pajak, mengatur pengeluaran dan penerimaan pemerintah, dan melakukan pinjaman pemerintah.

3. Kebijakan Non Moneter adalah kebijakan yang tidak berhubungan dengan finansial pemerintah maupun jumlah uang beredar. Misalnya: menekan tingkat rupiah dan melakukan pengawasan harga dan menetapkan harga secara maksimal.

2.3 Penelitian Terdahulu

\begin{tabular}{|l|l|l|l|l|}
\hline No & Peneliti & Judul & $\begin{array}{l}\text { Model } \\
\text { Penelitian }\end{array}$ & Hasil \\
\hline 1. & $\begin{array}{l}\text { Dicky Zunifar } \\
\text { Rizaldy }\end{array}$ & $\begin{array}{l}\text { Pengaruh Harga } \\
\text { Komoditas } \\
\text { Pangan Terhadap } \\
\text { Inflasi Di Kota } \\
\text { Malang Tahun } \\
\text { 2011-2016 }\end{array}$ & $\begin{array}{l}\text { Partial } \\
\text { Adjustment } \\
\text { Model (PAM) } \\
\text { dan Uji Asumsi } \\
\text { Klasik }\end{array}$ & $\begin{array}{l}\text { Jangka panjang } \\
\text { pada Uji PAM : } \\
\text { harga bawang } \\
\text { merah dan cabe } \\
\text { rawit berpengaruh } \\
\text { signifikan terhadap } \\
\text { besarnya inflasi di } \\
\text { Kota Malang. } \\
\text { Sama hal nya } \\
\text { dengan jangka } \\
\text { pendek. }\end{array}$ \\
\hline 2. & $\begin{array}{l}\text { Amelia } \\
\text { Ervina } \\
\text { Rotulung } \\
\text { (2013) }\end{array}$ & $\begin{array}{l}\text { Kontribusi Harga } \\
\text { Komoditi } \\
\text { Pertanian } \\
\text { Terhadap Inflasi } \\
\text { di Kota Manado }\end{array}$ & $\begin{array}{l}\text { Regresi linier } \\
\text { berganda. }\end{array}$ & $\begin{array}{l}\text { Kontribusi tertingi } \\
\text { pada komoditi } \\
\text { kacang-kacangan } \\
\text { sebesar 0,289 } \\
\text { persen dan } \\
\text { terendah pada }\end{array}$ \\
\hline
\end{tabular}




\begin{tabular}{|l|l|l|l|l|}
\hline & & & $\begin{array}{l}\text { buah-buahan } \\
\text { sebesar -0,438 }\end{array}$ \\
\hline 3. Sumaryanto & $\begin{array}{l}\text { Analisis } \\
\text { Volatilitas Harga } \\
\text { Eceran Beberapa } \\
\text { Komoditas } \\
\text { Pangan Utama } \\
\text { Dengan Model } \\
\text { ARCH/GARCH }\end{array}$ & $\begin{array}{l}\text { ARCH/GARCH } \\
\text { Univariat }\end{array}$ & $\begin{array}{l}\text { Hanya eceran } \\
\text { terdeflasi untuk } \\
\text { komoditas beras, } \\
\text { gula pasir, terigu, } \\
\text { cabai merah, dan } \\
\text { bawang merah } \\
\text { bersifat } \\
\text { heteroskedastik } \\
\text { sehingga model } \\
\text { peramalan yang } \\
\text { lebih sesuai adalah } \\
\text { ARCH/GARCH }\end{array}$ \\
& & & \\
\hline
\end{tabular}

\subsection{Hipotesis Penelitian}

- Hipotesis

Hipotesis 1

Ho : Tidak terdapat pengaruh positif harga komoditas pangan (ikan kerisi, bayam, cabai rawit, ikan tenggiri, beras, cumi-cumi, telur ayam ras, sawi hijau, jeruk dan apel) terhadap inflasi.

H1 : Terdapat pengaruh positif harga komoditas pangan (ikan kerisi, bayam, cabai rawit, ikan tenggiri, beras, cumi-cumi, telur ayam ras, sawi hijau, jeruk dan apel) terhadap inflasi.

- Kreteria Pengujian

Hipotesis 1

Ho tidak dapat ditolak jika :

t hitung $<\mathrm{t}$ tabel, atau sig. $\geq 0,05$ dan arah koefisien negatif.

H1 diterima jika :

t hitung $>$ t tabel, atau sig. $\leq 0,05$, dan arah koefisien Positif.

\section{METODEOLOGI}

Jenis data yang digunakan adalah data sekunder yang merupakan rangkaian waktu (Time series) dari tahun 2015-2017 dan data bulanan sebanyak 36 bulan. Data bulanan digunakan adalah data inflasi, harga ikan kerisi, harga bayam, harga cabai rawit, harga ikan tenggiri, harga beras, harga cumi-cumi, harga telur ayam ras, harga jeruk dan harga apel. Data sekunder diperoleh dari Badan Pusat Statistik Provinsi Kepulauan Bangka Belitung dan untuk melengkapi data yang diperlukan, digunakan data dan informasi yang diperoleh dari hasil penelitian terdahulu, buku, artikel, internet maupun perpustakaan serta publikasi-publikasi lain yang relavan. Sementara data sekunder bulanan inflasi dan harga komoditas diolah dengan menggnakan program Eviews9.

Data yang digunakan adalah data inflasi umum, dan harga komoditas pangan yang dipilih sesuai dengan andil inflasi dan deflasi tahun 2015-2018. Data ini adalah data bulanan dari bulan januari 2015-Desember 2017 (36 bulan). Data inflasi umum dan harga komoditas pangan tahunan dan bulanan bersumber dari Badan Pusat Statistik Provinsi Kepulauan Bangka Belitung dan dihitung menggunakan Eviews9. Interpolasi data dilakukan untuk menampilkan data bulanan yang berasal dari data tahunan 
Jenis penelitian ini adalah deskriptif kuantitatif. Studi deskriptif bertujuan untuk memperoleh driskriptif data yang mampu menggambarkan komposisi dan karakteristik dari unit yang diteliti dan data yang berupa angka-angka yang disesuaikan dari tujuan penelitian. Alat analisis yang digunakan adalah Model Regresi Berganda, dan Uji Asumsi Klasik (Uji Stasioner, Normalitas, Multiklonieritas, Heteroskedastisitas, dan Autokorelasi). Alat analisis ini digunakan untuk membuktikan berapa besar pengaruh variabel X terhadap Y.

\subsection{Teknis Analisis Data}

Teknis analisis data dilakukan dengan melihat apakah harga komoditas pangan tersebut berpengaruh signinifikan atau tidak terhadap inflasi di Kota Pangkalpinang tahun 2015-2017. Pengaruh variabel tersebut dilihat dari probabilitas pada hasil eviews tersebut. Jika model regresi berganda terpenuhi maka probabilitas harus lebih kecil dari 0,05. Sedangkan pada uji asumsi klasik nilai probabilitas harus lebih besar dari 0,05, kecuali pada uji stasioner. Uji Stasioner digunakan untuk melihat apakah data-data tersebut valid dan dapat digunakan pada analisis selanjutnya.

\section{HASIL DAN PEMBAHASAN}

\subsection{Deskripsi data}

\subsubsection{Inflasi}

Inflasi dikatakan sebagai suatu proses kenaikan harga, yaitu adanya kecenderungan bahwa harga barang meningkat secara umum yang terjadi terus menerus. Suatu barang dikatakan naik apabila harga barang tersebut lebih tinggi dari harga sebelumnya. Inflasi terjadi karena adanya kenaikan harga pada kelompok pengeluaran, diantaranya yaitu: kelompok bahan makanan jadi, minuman, rokok, tembakau, kelompok perumahan, air, listrik, dan bahan bakar, kelompok kesehatan dan kelompok pendidikan rekreasi, olahraga.

Dalam penelitian ini digunakan data inflasi dari Indeks Harga Konsumen di Kota Pangkalpinang.

Tabel. 4.1 Data Inflasi Kota Pangkalpinang

\begin{tabular}{lccc}
\hline Bulan & $\mathbf{2 0 1 5}$ & $\mathbf{2 0 1 6}$ & $\mathbf{2 0 1 7}$ \\
\hline Januari & 0,95 & 0,93 & 1,72 \\
Februari & $-0,89$ & 0,39 & $-1,11$ \\
Maret & $-0,46$ & 0,26 & 0,38 \\
April & $-0,87$ & $-0,95$ & 1,02 \\
Mei & $-0,61$ & $-0,11$ & $-0,93$ \\
Juni & $-0,14$ & 2,14 & 1,16 \\
\hline
\end{tabular}




\begin{tabular}{lccc}
\hline Juli & 3,18 & 1,16 & $-0,32$ \\
Agustus & 0,58 & 0,93 & $-0,78$ \\
September & 0,84 & 0,64 & 0,15 \\
Oktober & $-0,21$ & $-0,34$ & $-0,07$ \\
November & $-1,02$ & 0,56 & 0,12 \\
Desember & 1,56 & 1,95 & 1,33 \\
\hline
\end{tabular}

Sumber: Badan Pusat Statistik Kota Pangkalpinang

Pada tabel 4.1 dapat dilihat besaran inflasi periode Januari 2015 sampai Desember 2017 menunjukkan besaran inflasi yang berfluktuatif. Inflasi tertinggi terjadi pada bulan Juli tahun 2015 sebesar 3,18 persen. Hal ini disebabkan oleh indeks kelompok bahan makanan naik sebesar 6,11 persen. Selain itu, karena adanya libur sekolah dan perayaan keagamaan.

\subsubsection{Harga Ikan Kerisi}

Ikan Kerisi merupakan jenis ikan yang sering mengalami kenaikan harga pada setiap tahunnya. Ikan ini termasuk jenis ikan segar yang banyak di konsumsi oleh warga pangkalpinang dan sekitarnya. Sekarang Ikan kerisi berada pada posisi pertama dalam penyumbang inflasi Kota Pangkalpinang pada Juli 2018 sebesar 0,1652 persen.

Dalam penelitian ini digunakan harga komoditas Ikan Kerisi dapat dilihat dari statistik harga konsumen di Kota Pangkalpinang.

Tabel. 4.2 Harga Ikan Kerisi / Kg

\begin{tabular}{lccc}
\hline Bulan & $\mathbf{2 0 1 5}$ & $\mathbf{2 0 1 6}$ & $\mathbf{2 0 1 7}$ \\
\hline Januari & 53.750 & 47.500 & 47.500 \\
Februari & 50.000 & 35.000 & 41.250 \\
Maret & 36.250 & 38.125 & 45.000 \\
April & 45.000 & 31.250 & 45.000 \\
Mei & 40.000 & 31.250 & 41.250 \\
Juni & 3.250 & 35.625 & 40.000 \\
Juli & 48.333 & 45.000 & 47.188 \\
Agustus & 60.000 & 43.750 & 43.594 \\
September & 52.500 & 45.625 & 38.594 \\
\hline
\end{tabular}




\begin{tabular}{lccc}
\hline Oktober & 48.125 & 42.188 & 39.531 \\
November & 40.000 & 42.500 & 40.000 \\
Desember & 45.833 & 48.750 & 47.500 \\
\hline \multicolumn{4}{l}{} \\
\hline
\end{tabular}

Pada tabel 4.2 dapat dilihat besarnya harga Ikan Kerisi periode Januari 2015 sampai Desember 2017 menunjukkan harga yang berfluktuatif. Pada bulan Agustus tahun 2015 harga Ikan Kerisi menunjukkan harga tertinggi dari 2 tahun sesudahnya sebesar Rp. 60.000 per Kg. Hal ini disebabkan faktor cuaca yang kurang baik dan bulan terang, sehingga membuat para nelayan jarang melaut dan berdampak pada harga ikan-ikan.

Sedangkan pada bulan Desember tahun 2016 harga ikan kerisi tertinggi mencapai Rp. 48.750 per Kg. Sedangakan pada bulan Januari dan Desember terjadi kenaikan yang sama sebesar Rp. 47.500 per Kg. Hal ini karenakan bertepatan dengan hari raya keagamaan dan menyambut tahun baru.

\subsubsection{Harga Bayam}

Bayam merupakan salah satu komoditas pangan yang memiliki tingkat harga yang relatif tinggi. Pada tahun2018, inflasi pada bayam sebesar 0,1260 persen. Hal ini terjadi karena curah hujan yang cukup tinggi sehingga mengakibatkan para petani gagal panen.

Dalam penelitian ini digunakan harga komoditas Bayam dapat dilihat dari Statistik Harga Konsumen di Kota Pangkalpinang.

Tabel.4.3 Harga Bayam /Kg

\begin{tabular}{lccc}
\hline Bulan & $\mathbf{2 0 1 5}$ & $\mathbf{2 0 1 6}$ & $\mathbf{2 0 1 7}$ \\
\hline Januari & 8.000 & 10.000 & 11.063 \\
Februari & 8.000 & 20.000 & 13.500 \\
Maret & 7.500 & 16.000 & 11.000 \\
April & 8.000 & 10.000 & 9.250 \\
Mei & 7.000 & 9.500 & 9.188 \\
Juni & 6.000 & 13.500 & 9.531 \\
Juli & 9.333 & 9.500 & 10.063 \\
Agustus & 9.000 & 11.000 & 9.750 \\
\hline
\end{tabular}




\begin{tabular}{llll}
\hline Sepetmber & 9.000 & 11.000 & 9.625 \\
Oktober & 9.000 & 10.000 & 9.000 \\
November & 9.000 & 10.000 & 9.125 \\
Desember & 8.000 & 9.750 & 9.375 \\
\hline
\end{tabular}

Sumber: Badan Pusat Statistik Kota Pangkalpinang

Pada tabel 4.3 dapat dilihat bahwa besarnya harga bayam periode Januari 2015 sampai Desember 2017 menunjukkan harga yang berfluktuatif. Dari 3 tahun tersebut, harga bayam yang tertinggi berada pada bulan Februari 2016 yang mencapai 20.000. Hal ini terjadi karena adaya banjir selama 3 hari 2 malam sehinga stok bayam di Kota Pangkalpinang menjadi berkurang akibat dari gagal panen dan lambatnya jalan distribusi.

\subsubsection{Harga Cabai Rawit}

Cabai rawit merupakan salah satu komoditas pertanian yang sangat berpengaruh terhadap musim dan mudah busuk. Pada Tahun 2017, inflasi cabai mengalami fluktuasi harga yang relatif tinggi dan menjadi penyumbang inflasi sampai dengan sekarang ini. Fluktuasi harga Cabai Rawit ini disebabkan oleh faktor permintaan dan penawaran yang tinggi. Dalam penelitian ini digunakan harga komoditas Cabai Rawit dapat dilihat dari Statistik Harga Konsumen di Kota Pangkalpinang.

Tabel. 4.4 Harga Cabai Rawit / Kg

\begin{tabular}{lccc}
\hline Bulan & $\mathbf{2 0 1 5}$ & $\mathbf{2 0 1 6}$ & $\mathbf{2 0 1 7}$ \\
\hline Januari & 73.044 & 45.297 & 95.446 \\
Februari & 38.714 & 35.337 & 102.393 \\
Maret & 49.941 & 66.058 & 88.348 \\
\hline April & 43.837 & 44.199 & 61.518 \\
\hline Mei & 39.813 & 39.565 & 52.316 \\
\hline Juni & 35.776 & 38.366 & 45.678 \\
\hline Juli & 48.792 & 48.035 & 38.553 \\
\hline Agustus & 64.852 & 53.096 & 34.317 \\
\hline September & 60.335 & 42.370 & 30.974 \\
\hline Oktober & 31.821 & 40.146 & 29.299 \\
\hline November & 32.125 & 58.090 & 30.316 \\
\hline
\end{tabular}




\begin{tabular}{llll}
\hline Desember & 45.609 & 65.432 & 35.886
\end{tabular}

Sumber: Badan Pusat Statistik Kota Pangkalpinang

Pada tabel 4.4. dapat dilihat besarnya harga Cabai Rawit periode Januari 2015 sampai Desember 2017 menunjukkan harga yang berfluktuatif. Harga cabai rawit pada periode 2015-2017 mengalami kenaikan pada bulan Februari 2017 sebesar Rp 102.393. Hal ini disebabkan adanya gagal panen akibat hujan melanda di seluruh daerah sehingga mengakibatkan pasokan cabai rawit berkurang.

\subsubsection{Harga Ikan Tenggiri}

Ikan Tenggiri adalah jenis ikan segar yang sering mengalami kenaikan harga pada setiap tahunnya. Karena ikan ini sangat baik untuk dikonsumsi dan memberikan manfaat bagi kesehatan tubuh. Adapun manfaat yang diberikan adalah antara lain: mampu mengobati penyakit-penyakit ringan, mengatasi depresi, kanker,kecerdasan, pencernaa sehat, kolestrol, dan sebagainya. Ikan ini banyak mengandung zat besi, lemak, protein, dan juga vitamin A.

Dalam Penelitian ini digunakan harga komoditas Ikan Tenggiri dapat dilihat dari Statistik Harga Konsumen di Kota Pangkalpinang.

Tabel. 4.5 Harga Ikan Tengiri / Kg

\begin{tabular}{lccc}
\hline Bulan & $\mathbf{2 0 1 5}$ & $\mathbf{2 0 1 6}$ & $\mathbf{2 0 1 7}$ \\
\hline Januari & 75.000 & 74.375 & 69.688 \\
\hline Februari & 65.000 & 70.000 & 56.875 \\
\hline Maret & 47.500 & 69.375 & 65.000 \\
\hline April & 55.000 & 56.875 & 66.563 \\
\hline Mei & 57.500 & 53.750 & 63.750 \\
\hline Juni & 57.500 & 77.500 & 70.156 \\
\hline Juli & 83.333 & 74.375 & 73.750 \\
\hline Agustus & 78.750 & 55.000 & 71.250 \\
\hline September & 67.500 & 70.000 & 72.188 \\
\hline Oktober & 61.875 & 68.750 & 72.500 \\
\hline November & 51.250 & 68.438 & 74.219 \\
\hline Desember & 57.083 & 72.188 & 80.000 \\
\hline
\end{tabular}

Sumber: Badan Pusat Statistik Kota Pangkalpinang 
Pada tabel 4.5 dapat dilihat besaran harga ikan tenggiri pada periode Januari 2015 sampai Desember 2017 menunjukkan harga yang berflutuatif. Pada periode tahun tersebut, tahun 2015 yang menunjukkan harga tertinggi sebesar Rp 83.333. kenaikan ini terjadi dibulan juli 2015 dan disebabkan oleh tingginya permintaan masyarakat terhadap komoditas tersebut. Seperti yang kita lihat sekarang, Kota Pangkalpinang adalah ibu kota dari Provinsi Bangka Belitung dan merupakan daerah kepulauan, jadi untuk produksi ikan tenggiri lebih banyak di bandingkan daerah-daerah lain. Ikan tenggiri ini dijadikan bahan makanan seperti kemplang, pempek dan lempah kuning. Ikan tenggiri juga salah satu makanan khas dari Bangka Belitung. Penyebab lainnya adalah cuaca buruk dan bulan terang sehingga menyebabkan para nelayan belum bisa untuk melaut.

\subsubsection{Harga Beras}

Beras adalah salah satu komoditas pangan pemberi andil yang besar terhadap inflasi di Januari 2018 yang tercatat sebesar 0,62 persen. Kelompok pengeluaran bahan makanan tingkat inflasinya 2,34 persen dengan andilnya 0,48 persen, kemudian baru disusul dengan komoditas pangan lainnya. Kenaikan harga beras disebabkan karena kurangnya pasokan di beberapa daerah. Jika dalam suatu daerah pasokannya cukup, namun terkendala pada proses distribusi ke kota-kota sehingga harga dari beras tersebut mengalami kenaikan.

Dalam Penelitian ini digunakan harga komoditas Beras dapat dilihat dari Statistik Harga Konsumen di Kota Pangkalpinang.

Tabel.4.6 Harga Beras / Kg

\begin{tabular}{lccc}
\hline Bulan & $\mathbf{2 0 1 5}$ & $\mathbf{2 0 1 6}$ & $\mathbf{2 0 1 7}$ \\
\hline Januari & 10.263 & 11.423 & 11.552 \\
Februari & 10.450 & 11.423 & 11.523 \\
Maret & 10.817 & 11.367 & 11.387 \\
April & 10.176 & 11.270 & 11.416 \\
Mei & 9.963 & 11.303 & 11.665 \\
\hline Juni & 10.625 & 11.376 & 11.597 \\
\hline Juli & 10.947 & 11.566 & 11.578 \\
\hline Agustus & 10.624 & 11.518 & 11.620 \\
\hline September & 11.221 & 11.423 & 11.632 \\
\hline Oktober & 11.442 & 11.569 & 11.741 \\
\hline November & 11.245 & 11.579 & 11.764 \\
\hline
\end{tabular}




\begin{tabular}{llll}
\hline Desember & 11.325 & 11.535 & 11.876
\end{tabular}

Sumber: Badan Pusat Statistik Kota Pangkalpinang

Pada tabel 4.6 Dapat dilihat bahwa besarnya harga beras pada periode Januari 2015 sampai Desember 2017 menunjukkan harga yang berfluktuatif. Dari 3 tahun tersebut, harga beras yang tertinggi berada pada bulan Desember 2017 yang sudah mencapai Rp 11.876. Hal ini disebabkan karena adanya perayaan keagamaan atau menyambut bulan Rhamadan. Mengingat hampir 100 persen kebutuhan sembako dipasok dari luar daerah, kenaikan harga BBM menjadi salah satu penyebab kenaikan harga beras, sebab harga tingkat distributor mengalami kenaikan biaya transportasi dari pulau Jawa dan Sumatra ke pulau Bangka .

\subsubsection{Harga Cumi-cumi}

Cumi-cumi adalah salah satu komoditi pangan yang digemari oleh banyak orang. Cumi-cumi termasuk jenis bahan pangan seafood yang banyak ditemukan didaerah pantai seperti Indonesia bagian selatan. Cumicumi juga memiliki protein dan vitamin yang diklaim baik untuk hemoglobin dalam darah, memperkuat tulang, mensuplai kebutuhan protein dalam tubuh dan memperkuat perkembangan otak dan syaraf. Selain itu, cumi-cumi juga menjadi primadona di bidang kuliner karena olahannya yang disukai oleh banyak kalangan, baik tua ataupun muda. Karena itulah cumi-cumi telah menjadi penyumbang inflasi/deflasi pada bahan makanan. Pada tahun 2018 cumi-cumi mengalami deflasi sebesar $-0,0407$ persen di Kota Pangkalpinang.

Dalam Penelitian ini digunakan harga komoditas Cumi-cumi dapat dilihat dari Statistik Harga Konsumen di Kota Pangkalpinang.

Tabel. 4.7 Harga Cumi-cumi /Kg

\begin{tabular}{lccc}
\hline Bulan & $\mathbf{2 0 1 5}$ & $\mathbf{2 0 1 6}$ & $\mathbf{2 0 1 7}$ \\
\hline Januari & 52.500 & 51.875 & 54.167 \\
Februari & 46.875 & 43.750 & 53.333 \\
Maret & 42.500 & 47.500 & 60.000 \\
April & 46.750 & 44.373 & 62.500 \\
Mei & 46.250 & 33.750 & 51.458 \\
Juni & 45.000 & 48.125 & 51.250 \\
Juli & 53.333 & 47.500 & 52.083 \\
Agustus & 47.500 & 42.500 & 50.625 \\
September & 52.500 & 45.833 & 50.625 \\
\hline
\end{tabular}




\begin{tabular}{lccc}
\hline Oktober & 40.000 & 49.167 & 53.125 \\
November & 37.500 & 42.500 & 54.375 \\
Desember & 49.583 & 45.938 & 58.750 \\
\hline \multicolumn{2}{l}{ Sumber: Badan Pusat Statistik Kota Pangkalpinang }
\end{tabular}

Pada tabel 4.7 dapat dilihat bahwa besarnya harga beras pada periode Januari 2015 sampai Desember 2017 menunjukkan harga yang berfluktuatif. Dari 3 tahun tersebut, harga cumi-cumi yang tertinggi berada pada bulan Maret 2017 yang mencapai Rp60.000. Hal ini disebabkan karena terbatasnya pasokan. Keterbatasan ini sebagian besar para nelayan belum turun ke laut, karena nelayan masih menikmati libur lebaran bersama anggota keluarga mereka. Selain itu, permintaan masyarakat pun naik, sebab banyak dibukanya rumah-rumah makan.

\subsubsection{Harga Telur Ayam Ras}

Telur ayam ras adalah salah satu komoditas yang memiliki fluktuasi harga yang cukup tinggi. Flutuasi tersebut dapat disebabkan oleh faktor permintaan dan penawaran.

Dalam Penelitian ini digunakan harga komoditas Telur ayam ras dapat dilihat dari Statistik Harga Konsumen di Kota Pangkalpinang.

Tabel. 4.8 Harga Telur Ayam / Kg

\begin{tabular}{llll}
\hline Bulan & $\mathbf{2 0 1 5}$ & $\mathbf{2 0 1 6}$ & $\mathbf{2 0 1 7}$ \\
\hline Januari & 1.246 & 1.281 & 1.365 \\
Februari & 1.140 & 1.290 & 1.400 \\
Maret & 1.156 & 1.260 & 1.400 \\
\hline April & 1.175 & 1.200 & 1.238 \\
Mei & 1.210 & 1.210 & 1.275 \\
\hline Juni & 1.225 & 1.250 & 1.320 \\
\hline Juli & 1.225 & 1.250 & 1.338 \\
\hline Agustus & 1.235 & 1.250 & 1.375 \\
\hline September & 1.250 & 1.250 & 1.300 \\
\hline Oktober & 1.231 & 1.200 & 1.300 \\
\hline November & 1.215 & 1.150 & 1.300 \\
\hline Desember & 1.215 & 1.133 & 1.306 \\
\hline
\end{tabular}


Sumber: Badan Pusat Statistik Kota Pangkalpinang

Pada tabel 4.8 dapat dilihat bahwa besarnya harga beras pada periode Januari 2015 sampai Desember 2017 menunjukkan harga yang berfluktuatif. Dari 3 tahun tersebut, harga beras yang tertinggi berada pada bulan Februari dan Maret 2017 yang mencapai Rp 1.400. Hal ini disebabkan karena adanya perayaan keagamaan seiring dengan permintaan yang meningkat drastis.

\subsubsection{Harga Sawi Hijau}

Sawi hijau adalah salah satu komoditas sayuran yang memiliki banyak manfaat diantaranya mengandung vitamin $\mathrm{A}$, vitamin $\mathrm{C}$ untuk Imun, kalsium, mencegah dehidrasi dan meningkatkan nafsu makan. Karena itulah harga sawi hijau berfluktuatif pada setiap tahunnya dan sawi hijau didapat sesuai dengan keadaan cuaca yang mendukung untu bercocok tanam. Sawi hijau juga menjadi penyumbang inflasi periode 2018 dengan andil 0,24 persen.

Dalam Penelitian ini digunakan harga komoditas Sawi Hijau dapat dilihat dari Statistik Harga Konsumen di Kota Pangkalpinang.

Tabel.4.9 Harga Sawi Hijau / Kg

\begin{tabular}{lccc}
\hline Bulan & $\mathbf{2 0 1 5}$ & $\mathbf{2 0 1 6}$ & $\mathbf{2 0 1 7}$ \\
\hline Januari & 10.000 & 13.500 & 15.450 \\
Februari & 8.000 & 21.000 & 16.950 \\
\hline Maret & 9.000 & 17.500 & 10.950 \\
\hline April & 17.500 & 15.000 & 9.450 \\
\hline Mei & 11.000 & 15.000 & 16.300 \\
\hline Juni & 6.500 & 15.000 & 15.467 \\
\hline Juli & 8.000 & 11.250 & 11.883 \\
\hline Agustus & 13.500 & 12.000 & 13.567 \\
\hline September & 11.500 & 10.000 & 10.883 \\
\hline Oktober & 12.500 & 11.000 & 12.383 \\
\hline November & 13.500 & 12.500 & 12.083 \\
\hline Desember & 13.000 & 11.625 & 9.983 \\
\hline
\end{tabular}

Sumber: Badan Pusat Statistik Kota Pangkalpinang

Pada tabel 4.9 dapat dilihat bahwa besarnya harga beras pada periode Januari 2015 sampai Desember 2017 menunjukkan harga yang berfluktuatif. 
Dari 3 tahun tersebut, harga beras yang tertinggi berada pada bulan Februari 2016 yang sudah mencapai $\mathrm{Rp} 21.000$. Hal ini disebabkan karena adaya banjir selama 3 hari 2 malam sehinga stok sawi hijau di Kota Pangkalpinang menjadi berkurang akibat dari gagal panen dan lambatnya jalan distribusi.

\subsubsection{Harga Jeruk}

Jeruk adalah salah satu komoditas buah-buahan yang banyak mengandung vitamin C. Harga pada buah jeruk naik turun, karena disebabkan oleh faktor permintaan dan penawaran. Jeruk telah menjadi andil inflasi terbesar pada tahun 2016 sebesar 0,44 persen.

Dalam Penelitian ini digunakan harga komoditas Jeruk dapat dilihat dari Statistik Harga Konsumen di Kota Pangkalpinang.

Tabel. 4.10 Harga Jeruk / Kg

\begin{tabular}{lccc}
\hline Bulan & $\mathbf{2 0 1 5}$ & $\mathbf{2 0 1 6}$ & $\mathbf{2 0 1 7}$ \\
\hline Januari & 23.500 & 24.500 & 25.000 \\
\hline Februari & 24.000 & 22.500 & 23.500 \\
\hline Maret & 24.000 & 25.000 & 22.000 \\
\hline April & 22.500 & 27.500 & 25.000 \\
\hline Mei & 21.500 & 30.000 & 24.375 \\
\hline Juni & 23.500 & 29.500 & 22.168 \\
\hline Juli & 25.000 & 30.000 & 18.500 \\
\hline Agustus & 22.500 & 27.500 & 19.500 \\
\hline September & 21.500 & 27.500 & 19.500 \\
\hline Oktober & 22.000 & 27.500 & 19.500 \\
\hline November & 22.500 & 22.750 & 21.250 \\
\hline Desember & 25.750 & 25.750 & 21.250 \\
\hline
\end{tabular}

Sumber: Badan Pusat Statistik Kota Pangkalpinang

Pada tabel 4.10 Dapat dilihat bahwa besarnya harga beras pada periode Januari 2015 sampai Desember 2017 menunjukkan harga yang berfluktuatif. Dari 3 tahun tersebut, harga beras yang tertinggi berada pada bulan Mei dan Juli 2016 yang sudah mencapai Rp 30.000. Hal ini disebabkan kenaikan kelompok pengeluaran dan terjadi cuaca buruk yang tidak menentu sehingga menyebabkan daerah tersebut menjadi gagal panen dan pengiriman barang pun terhambat.

\subsubsection{Harga Apel}


Apel adalah salah satu komoditas buah-buahan juga yang kaya akan nutrisi, membantu menurunkan berat badan dan menjaga kesehatan jantung. Apel juga menjadi andil inflasi terbesar pada tahun 2016 sebesar 0,16.

Dalam Penelitian ini digunakan harga komoditas Apel dapat dilihat dari Statistik Harga Konsumen di Kota Pangkalpinang.

Tabel. 4.11 Harga Apel / Kg

\begin{tabular}{lccc}
\hline Bulan & $\mathbf{2 0 1 5}$ & $\mathbf{2 0 1 6}$ & $\mathbf{2 0 1 7}$ \\
\hline Januari & 33.333 & 38.333 & 31.975 \\
\hline Februari & 42.222 & 35.000 & 31.975 \\
\hline Maret & 42.222 & 41.000 & 35.225 \\
\hline April & 35.000 & 41.667 & 32.225 \\
\hline Mei & 38.333 & 49.000 & 33.567 \\
\hline Juni & 40.000 & 47.500 & 33.970 \\
\hline Juli & 42.500 & 48.333 & 34.400 \\
\hline Agustus & 40.000 & 44.167 & 34.400 \\
\hline September & 35.000 & 51.333 & 35.650 \\
\hline Oktober & 32.500 & 38.333 & 36.650 \\
\hline November & 34.167 & 40.000 & 37.900 \\
\hline Desember & 35.000 & 43.333 & 36.900 \\
\hline Sumber: Badan Pusat Statistik Kota Pangkalpinang
\end{tabular}

Pada tabel 4.11 dapat dilihat bahwa besarnya harga beras pada periode Januari 2015 sampai Desember 2017 menunjukkan harga yang berfluktuatif. Dari 3 tahun tersebut, harga beras yang tertinggi berada pada bulan September 2016 yang mencapai Rp 51.333. Penyebabnya sama dengan yang terjadi pada harga jeruk.

\subsection{Analisis Data}

\subsubsection{Hasil Analisis Regresi Berganda}

Pada hasil analisis ini digunakan untuk mengetahui seberapa besar pengaruh Harga Komoditas Pangan (X) terhadap Inflasi (Y) dari tahun 2015 sampai 2017. Adapun harga komoditas (X) yang digunakan adalah harga ikan kerisi, harga bayam, harga cabai rawit, harga ikan tenggiri, harga beras, harga cumi-cumi, harga telur ayam ras, harga sawi hijau, harga jeruk dan harga apel. 
Tabel 4.12 Analisis Regresi Berganda

Dependent Variable: INFLASI

Method: Least Squares

Date: 08/22/18 Time: 10:36

Sample: 2015M01 2017M12

Included observations: 36

\begin{tabular}{lrrrr}
\hline \hline \multicolumn{1}{c}{ Variable } & Coefficient & Std. Error & t-Statistic & Prob. \\
\hline \hline LNX1 (ikan kerisi) & 0.271063 & 1.412758 & 0.191868 & 0.8494 \\
LNX2(bayam) & -0.021831 & 1.097827 & -0.019885 & 0.9843 \\
LNX3(cabai rawit) & 0.560407 & 0.639303 & 0.876590 & 0.3891 \\
LNX4 (ikan tenggiri) & 4.580637 & 1.791441 & 2.556957 & 0.0170 \\
LNX5 (beras) & 2.668488 & 4.099819 & 0.650879 & 0.5211 \\
LNX6(cumi-cumi) & -0.193532 & 2.034042 & -0.095146 & 0.9250 \\
LNX7(telur ayam ras) & -1.646572 & 4.032566 & -0.408319 & 0.6865 \\
LNX8( sawi hijau) & -0.773500 & 0.882753 & -0.876236 & 0.3892 \\
LNX9(jeruk) & 3.273473 & 1.845834 & 1.773438 & 0.0883 \\
LNX10(apel) & -0.657961 & 1.930172 & -0.340882 & 0.7360 \\
\multicolumn{1}{c}{ C } & -89.01435 & 46.82194 & -1.901125 & 0.0689 \\
\hline \hline R-squared & 0.553712 & Mean dependent var & 0.365000 \\
Adjusted R-squared & 0.375196 & S.D. dependent var & 1.020771 \\
S.E. of regression & 0.806864 & Akaike info criterion & 2.655145 \\
Sum squared resid & 16.27573 & Schwarz criterion & 3.138998 \\
Log likelihood & -36.79260 & Hannan-Quinn criter. & 2.824022 \\
F-statistic & 3.101760 & Durbin-Watson stat & 2.312294 \\
Prob(F-statistic) & 0.010492 & & \\
\hline \hline
\end{tabular}

4.2.1.1 Persamaan Regresi

$Y=a+b 1 \times 1-b 2 \times 2+b 3 \times 3+b 4 x 4+b 5 x 5-b 6 x 6-b 7 x 7-b 8 x 8+b 9 x 9-b 10 \times 10+e$

Inflasi $=-89,01435+0,271063$.Harga ikan kerisi - 0,021831.Harga bayam+ 0,560407 . Harga cabai rawit+ 4,580637. Harga ikan tenggiri $+2,668488$. Harga beras $-0,193532$. Harga cumi-cumi $-1,646572$. Harga telur ayam ras 0,773500.Harga sawi hijau $+3,273473$. Harga jeruk $-0,657961$. Harga apel.

\subsubsection{Uji F}

Uji F digunakan untuk menguji ketepatan model (goodness of fit). Uji F ini sering disebut dengan uji simultan, yaitu untuk menguji apakah model masuk dalam kategori cocok ( fit) atau tidak. Uji F dilakukan dengan cara melihat nilai probability F-statistik $>\alpha=0,05$ maka Ho ditolak dan $\mathrm{H} 1$ diterima.

Dari hasil regresi tersebut uji $\mathrm{F}$ dapat diketahui bahwa nilai probability $\mathrm{F}$ statistic $0,010492<\alpha(0,05)$ maka Ho ditolak dan H1 diterima, hal ini berarti harga komoditas pangan secara bersama-sama memiliki pengaruh signifikan ter hadap inflasi atau model dinyatakan cocok atau fit. 


\subsubsection{Uji T}

Uji T digunakan untuk menguji apakah variabel tersebut berpengaruh secara signifikan terhadap variabel tergantung atau tidak. Uji t dilakukan dengan cara melihat nilai dari masing-masing probability $t$-statistic dari setiap variabel bebas. Jika nilai probability $>\alpha=0,05$, maka Ho diterima dan $\mathrm{H}_{1}$ ditolak, sebaliknya jika nilai probability $<\alpha=0,05$, maka Ho ditolak dan $\mathrm{H}_{1}$ diterima. Berikut analisis uji $\mathrm{t}$ diatas :

- Prob LNX1 $(0,8494)>0,05$, maka Ho diterima dan H1 ditolak, ini dapat disimpulkan bahwa variabel harga ikan kerisi berpengaruh negatif terhadap inflasi di Kota Pangkalpinang pada tahun 2015 sampai 2017. Setiap perubahan harga ikan kerisi sebesar 1 persen akan menyebabkan perubahan inflasi sebesar 0,271063 persen.

- Prob LNX2 $(0,9843)>0,05$, maka Ho diterima dan H1 ditolak, ini dapat disimpulkan bahwa variabel harga bayam berpengaruh negatif terhadap inflasi di Kota Pangkalpinang pada tahun 2015 sampai 2017. Setiap perubahan harga bayam sebesar 1 persen akan menyebabkan perubahan inflasi sebesar -0,021831 persen.

- Prob LNX3 $(0,3891)>0,05$, maka Ho diterima dan H1 ditolak , ini dapat disimpulkan bahwa variabel harga cabai rawit berpengaruh negatif terhadap inflasi di Kota Pangkalpinang pada tahun 2015 sampai 2017. Setiap perubahan harga cabai rawit sebesar 1 persen akan menyebabkan perubahan inflasi sebesar 0,560407 persen.

- Prob LNX4 $(0,0170)<0,05$, makaHo ditolak dan H1 diterima, ini dapat disimpulkan bahwa variabel harga ikan tenggiri berpengaruh positif terhadap inflasi di Kota Pangkalpinang pada tahun 2015 sampai 2017. Setiap perubahan harga ikan tenggiri sebesar 1 persen akan menyebabkan perubahan inflasi sebesar 4,580637 persen.

- Prob LNX5 $(0,5211)>0,05$, maka Ho diterima dan H1 ditolak, ini dapat disimpulkan bahwa variabel harga beras berpengaruh negatif terhadap inflasi di Kota Pangkalpinang pada tahun 2015 sampai 2017. Setiap perubahan harga beras sebesar 1 persen akan menyebabkan perubahan inflasi sebesar 2,668488 persen.

- Prob LNX6 $(0,9250)>0,05$, maka Ho diterima dan H1 ditolak, ini dapat disimpulkan bahwa variabel harga cumi-cumi berpengaruh negatif terhadap inflasi di Kota Pangkalpinang pada tahun 2015 sampai 2017. Setiap perubahan harga cumi-cumi sebesar 1 persen akan menyebabkan perubahan inflasi sebesar $-0,193532$ persen.

- Prob LNX7 $(0,6865)>0,05$, maka Ho diterima dan H1 ditolak, ini dapat disimpulkan bahwa variabel telur ayam ras berpengaruh negatif terhadap inflasi di Kota Pangkalpinang pada tahun 2015 sampai 2017. Setiap perubahan harga telur ayam ras sebesar 1 persen akan menyebabkan perubahan inflasi sebesar 1,646572 persen.

- Prob LNX8 $(0,3892)>0,05$, maka Ho diterima dan H1 ditolak, ini dapat disimpulkan bahwa variabel sawi hijau berpengaruh negatif terhadap inflasi di Kota Pangkalpinang pada tahun 2015 sampai 2017. Setiap perubahan harga sawi hijau sebesar 1 persen akan menyebabkan perubahan inflasi sebesar $-0,773500$ persen.

- Prob LNX9 $(0,7360)>0,05$, maka Ho diterima dan H1 ditolak, ini dapat disimpulkan bahwa variabel jeruk berpengaruh negatif terhadap inflasi di Kota 
Pangkalpinang pada tahun 2015 sampai 2017. Setiap perubahan harga Jeruk sebesar 1 persen akan menyebabkan perubahan inflasi sebesar 3,273473 persen.

- Prob LNX10 $(0,0689)>0,05$, maka Ho diterima dan H1 ditolak, ini dapat disimpulkan bahwa variabel jeruk berpengaruh negatif terhadap inflasi di Kota Pangkalpinang pada tahun 2015 sampai 2017. Setiap perubahan harga apel sebesar 1 persen akan menyebabkan perubahan inflasi sebesar $-0,657961$ persen.

\subsubsection{Uji Asumsi Klasik}

Tabel 4.13 Uji Stasioner

Null Hypothesis: Unit root (individual unit root process)

Series: INFLASI__ , LNX1, LNX2, LNX3, LNX4, LNX5, LNX6, LNX7, LNX8,

LNX9, LNX10

Date: 08/22/18 Time: 11:05

Sample: 2015M01 2017M12

Exogenous variables: Individual effects, individual linear trends

Automatic selection of maximum lags

Automatic lag length selection based on AIC: 0 to 8

Total number of observations: 352

Cross-sections included: 11

\begin{tabular}{lcc}
\hline \hline Method & Statistic & Prob. $^{* *}$ \\
\hline ADF - Fisher Chi-square & 49.0740 & 0.0008 \\
ADF - Choi Z-stat & -3.83270 & 0.0001 \\
\hline \hline${ }^{* *}$ Probabilities for Fisher tests are computed using an asymptotic Chi \\
-square distribution. All other tests assume asymptotic normality.
\end{tabular}

Sumber : Data diolah

Prob $(0,0008)<0,05$ maka Ho ditolak dan H1 diterima, ini berarti bahwa data tersebut mengandung stasioner atau valid dan dapat digunakan pada analisis selanjutnya.

Tabel 4.14 Uji Normalitas

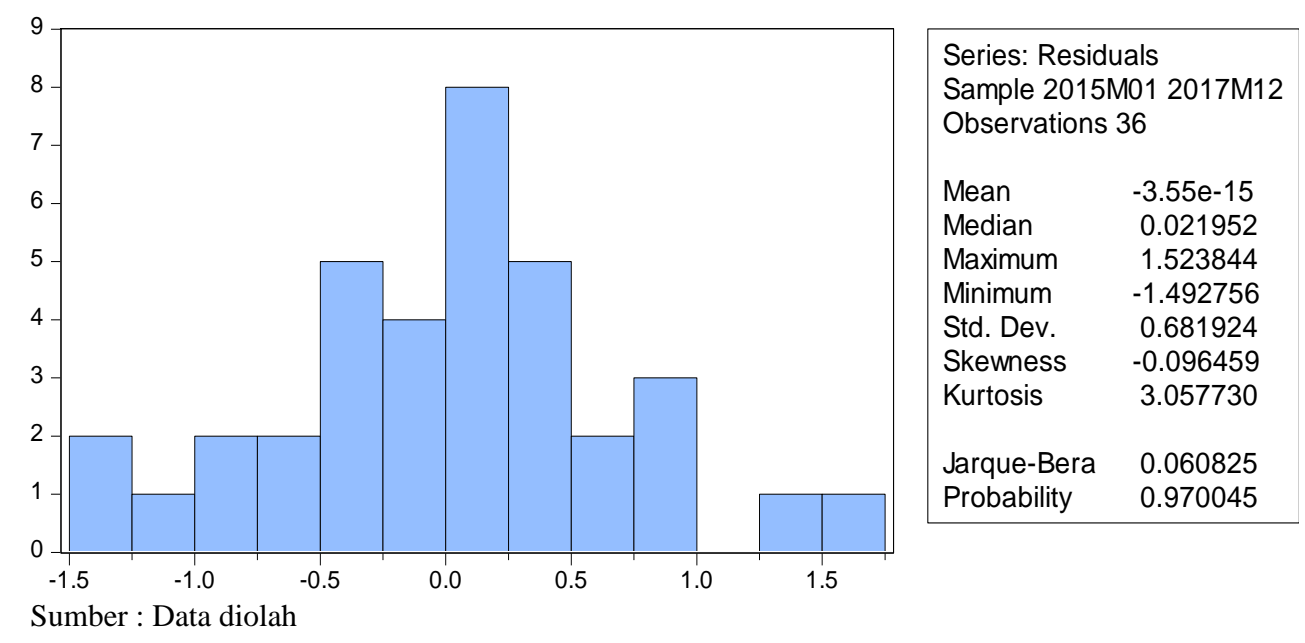


Prob pada Jarque-Bera sebesar $(0,970045)>0,05$, maka Ho diterima dan H1 ditolak ini berarti bahwa nilai residual terstandarisasi berdistribusi normal.

Tabel 4.15 Uji Multikolonieritas

Variance Inflation Factors

Date: 08/22/18 Time: 10:37

Sample: 2015M01 2017M12

Included observations: 36

\begin{tabular}{cccc}
\hline \hline & \multicolumn{3}{c}{ Uncentere } \\
Variable & $\begin{array}{c}\text { Coefficient } \\
\text { Variance }\end{array}$ & $\begin{array}{c}\text { VIF } \\
\text { VIF }\end{array}$ & $\begin{array}{c}\text { Centered } \\
\text { VIF }\end{array}$ \\
\hline \hline LNX1 & 1.995884 & 12552.74 & 2.311938 \\
LNX2 & 1.205224 & 5621.026 & 3.064030 \\
LNX3 & 0.408709 & 2617.502 & 2.309002 \\
LNX4 & 3.209260 & 21869.01 & 3.251033 \\
LNX5 & 16.80851 & 80896.42 & 1.702869 \\
LNX6 & 4.137325 & 26625.18 & 3.523046 \\
LNX7 & 16.26159 & 45755.94 & 2.545735 \\
LNX8 & 0.779252 & 3822.222 & 2.541143 \\
LNX9 & 3.407105 & 19121.58 & 2.728800 \\
LNX10 & 3.725565 & 22924.35 & 3.353263 \\
C & 2192.294 & 121227.4 & NA \\
\hline \hline
\end{tabular}

Sumber: Data diolah

Dengan Melihat VIF, Semua VIF pada variabel ini kurang dari 10 maka model regresi tidak ada multikolonieritas.

Tabel 4.16 Uji heteroskedastitas

Heteroskedasticity Test: Breusch-Pagan-Godfrey

\begin{tabular}{|c|c|c|c|}
\hline F-statistic & 1.122125 & $\begin{array}{l}\text { Prob. F(10,25) } \\
\text { Prob. Chi- }\end{array}$ & 0.3850 \\
\hline $\begin{array}{l}\text { Obs*R-squared } \\
\text { Scaled explained }\end{array}$ & 11.15271 & $\begin{array}{l}\text { Square }(10) \\
\text { Prob. Chi- }\end{array}$ & 0.3457 \\
\hline SS & 5.533676 & Square(10) & 0.8528 \\
\hline
\end{tabular}

Sumber : Data diolah

Prob $(0,3457)>0,05$, maka Ho diterima dan $\mathrm{H} 1$ ditolak atau model regresi bersifat homokedastisitas.

Tabel 4.17 Uji Autokorelasi

Breusch-Godfrey Serial Correlation LM Test:

\begin{tabular}{llll}
\hline \hline F-statistic & 1.002699 & Prob. F(2,23) & 0.3824 \\
Obs ${ }^{\star}$ R-squared & 2.887149 & Prob. Chi-Square(2) & 0.2361
\end{tabular}


Sumber: Data diolah

Prob $\mathrm{F}(0,3824)>0,05$, maka Ho diterima dan $\mathrm{H} 1$ ditolak atau model regresi tidak mengandung masalah autokorelasi.

\section{KESIMPULAN}

Dari hasil penelitian, koefisien determinasi atau R-square sebesar 0,553712 ini berarti variasi inflasi dapat dijelaskan oleh variasi harga komoditas pangan sebesar 55,3 persen atau menunjukkan bahwa variasi harga komoditas pangan ini mampu mempengaruhi inflasi sebesar 55,3 persen dan sisanya dijelaskan oleh variabel lainnya.

Berdasarkan berita resmi statistikdi Badan Pusat Statistik harga komditas pangan memberikan andil inflasi di Kota Pangkalpinang tahun 2015-2017. Harga ikan tenggiri memiliki pengaruh positif terhadap inflasi di Kota Pangkalpinang, yang ditunjukkan oleh nilai koefisien sebesar 4,58063. Nilai koefisien ini signifikan karena probabilitas sebesar $0,0170<0,05$ maka Ho ditolak dan H1 terima. Artinya ketika harga ikan tenggiri itu naik maka inflasi akan naik. Selain itu, harga komoditas pangan lainnya memiliki pengaruh negatif terhadap inflasi di Kota Pangkalpinang artinya ketika harga komoditas pangan ini naik maka inflasi akan turun.

Harga ikan tenggiri memiliki pengaruh positif disebabkan karena banyaknya permintaan masyarakat Kota Pangkalpinang akan ikan tenggiri. Ikan tenggiri di Kota Pangkalpinang dijadikan sebagai sumber rezeki bagi masyarakat Kota Pangkalpinang, sebab ikan tenggiri merupakah salah satu makanan khas dari Bangka Belitung yang dominannya pengahasil makanan laut.Ikan tenggiri di Kota Pangkalpinang diproduksi dalam pengolahan makanan seperti pempek, kerupuk.Sedangkan komoditas pangan yang memiliki pengaruh negatif disebabkan oleh tingkat harga yang rendah seperti harga sayuran, telur yang memilliki harga rendah dibandingkan harga ikan yang lebih tinggi dipasaran. Selain itu komoditas pangan ini bukan sebagai bahan konsumsi setiap hari, pengaruh ke masyarakat rendah karena yang berpengaruh besar terhadap inflasi adalah minyak, tarif lstrik, rumah dan lain-lain.

\section{UCAPAN TERIMA KASIH}

Penulis menyadari banyak kekurangan dalam penulisan penelitian ini. Oleh karena itu penulis sangat membutuhkan masukan maupun kritik yang membangun. Penulis mengucapkan terima kasih kepada seluruh pihak yang terlibat dalam penelitian ini. Terutama Orang tua, dosen pembimbing, pihak instansi serta teman-teman yang telah membantu dalam penyelesaian penelitian tersebut.

\section{REFERENSI}

\section{Artikel :}

Adwin S.Atmadja.1999.Inflasi Indonesia: Sumber-sumber Penyebab dan Pengendaliannya. Jurnal Akuntansi dan Keuangan.Vol. No, 1 Mei 1999 Universitas Kristen Petra.

Amelia Ervina Rotulung.2013. Kontribusi Harga Komoditi Pertanian Terhadap Inflasi di Kota Manado (dibawah bimbingan Charles R. Ngangi sebagai ketua, O. Esry. H. Laoh dan Melissa L.G.Tarore sebagai Anggota

Buku : 
Dr. Suliyanto.2011.Ekonometrika Terapan: Teori dan Aplikasi dengan SPSS.Yogyakarta: CV.Andi OFFSET.

Kotler,Philip dan Gary Armstrong.2012. Prinsip-prinsip Pemasaran Edisi 13 Jilid 1.Jakarta:Erlangga.

Purnawati H Purwono, Heni Purnamawati.2007.Budidaya 8 Jenis Tanaman Pangan Unggul.Jakarta:Penebar Swadya.

Riyadi.2003.Perencanaan Pembangunan Daerah : strategi menggali potensi dalam mewujudkan otonomi daerah: Gramedia pustaka utama

\section{For an organizational or government report or document with no author :}

Badan Pusat Statistika. 2015. Indeks Harga Konsumen dan Inflasi Kota Pangkalpinang 2015. Bangka Belitung

Badan Pusat Statistika. 2016. Indeks Harga Konsumen dan Inflasi Kota Pangkalpinang 2016. Bangka Belitung

Badan Pusat Statistika. 2017. Indeks Harga Konsumen dan Inflasi Kota Pangkalpinang 2017. Bangka Belitung

Badan Pusat Statistika. 2015. Statistik Harga Konsumen Kota Pangkalpinang 2015. Bangka Belitung

Badan Pusat Statistika. 2016. Statistik Harga Konsumen Kota Pangkalpinang 2016. Bangka Belitung

Badan Pusat Statistika. 2017. Statistik Harga Konsumen Kota Pangkalpinang 2017. Bangka Belitung

Badan Pusat Statistika.2015. Berita Resmi Statistik, Provinsi Kepulauan Bangka Belitung 2015. Bangka Belitung.

Badan Pusat Statistika.2016. Berita Resmi Statistik, Provinsi Kepulauan Bangka Belitung 2016. Bangka Belitung.

Badan Pusat Statistika.2017. Berita Resmi Statistik, Provinsi Kepulauan Bangka Belitung 2017. Bangka Belitung.

Badan Pusat Statistika.2018. Berita Resmi Statistik, Provinsi Kepulauan Bangka Belitung 2018. Bangka Belitung.

Boediono.1992. Teori Pertumbuhan Ekonomi.Yogyakarta: BEPFE UGM. Dicky Zunifar Rizaldy.2017. Pengaruh Harga Komoditas Pangan di Kota Malang.Jurnal Ekonomi Pembangunan. Vol.15,No.2, Desember 2017. 